\title{
British Counterinsurgency in Malaya: Population Control, Intelligence and Military Operations
}

Great Britain scored a military victory in the colonial campaign it fought in Malaya from 1948 to 1960. At the end this conflict its army controlled the disputed territory, having systematically defeated, rooted out and forced their enemies into hiding or across international borders ${ }^{1}$. Despite that, the conflict ended with the colonial power leaving the land and recognizing its independence. Although the British left Malaya in the hands of a friendly government representing the local economic elite and all too willing to make military and economic concessions to the former colonial power the result was a military victory combined with a cessation of formal imperial ties ${ }^{2}$.

The Malayan campaign was a brutal affair in which tens of thousands lost their lives and hundreds of thousands were displaced. Both the government and the insurgents may have followed noble, generous goals, but in doing so they wrought pain and suffering on many innocents. In a pattern that has very little to do with the stated aims of the guerrillas and the professed democratic values of the governments, the conclusion of the conflict was reached through violence and bloodshed.

This paper will discuss the Malayan Emergency in the following format: the first section presents the political, economic and military context of the conflict, with a focus on internal and foreign aspects. The second section is concerned with population control, featuring a discussion of the deportations, resettlement and destruction of villages, food rationing, identity controls and propaganda aimed at civilians. The third part will deal with intelligence, focusing on the evolution and types of information-gathering and intelligenceanalysis and how this was relayed to military units. The fourth section is a presentation of military operations, most prominently sweeps, patrols, ambushes, deep strikes, air operations, and the use of counter-gangs and of propaganda aimed at guerrillas; it also features examples concerning the elimination of some of the insurgent groups and leaders.

\section{The political and military context}

When the military crisis irrupted in Malaya in June 1948 the situation in the British colony had been seriously degrading for a number of years. Some of the pro-British authors, writing close to the events or even close to our days and influent in the subsequent literature had such rosy views of the colonial situation that make them quaint now. Noel Barber, a

\footnotetext{
${ }^{1}$ The Malayan insurgents did not see things this way. In their memoirs, the communists never refer to 1960 as the year of their defeat; see Fong Chong Pik, The Memoirs of a Malayan Communist Revolutionary, Petaling Jaya: SIRD, 2008 and Rashid Maidin, The Memoirs of Rashid Maidin. From Armed Struggle to Peace, Petaling Jaya: SIRD, 2009.

${ }_{2}^{2}$ Barbara Watson Andaya, Leonard Y. Andaya, A History of Malaysia, Honolulu: University of Hawai i Press, 2001; T.N. Harper, The End of Empire and the Making of Malaya, Cambridge: Cambridge University Press, 1999.
} 
journalist whose book on the war was widely read and quoted ever since its publication, had no qualms in making a statement such as: "[i]n 1948 Malaya (...) had achieved a rare distinction: it was a contented paradise in which men of many skins and creeds lived in harmony, enjoying the highest standard of living as the country moved quietly but firmly and without any strife - to the day when it would be granted independence from the British (...)." ${ }^{3}$ Gregory Blaxland, a military historian of post-1945 British campaigns, sees uniformly Malaya as the richest part of the Empire and an economic success story ${ }^{4}$. In this land many races and creeds "lived in harmony and enjoyed one of the highest standards of living in all Asia". 5

Obviously, the situation could have looked this way from the perspective of the approximately 12000 white planters and engineers mostly living on the rich western side of the peninsula ${ }^{6}$ and the few thousands British officers and administrative officials which, together with the ruling Malay princes and the heavily-Chinese local bourgeoisie enjoyed the benefits of one of the world's greatest sources of rubber and $\operatorname{tin}^{7}$, as well as the trade flowing through the highly strategic port of Singapore. For the rest of the population, divided amongst three main ethnicities with 49\% ethnic Malay, $39 \%$ Chinese and 12\% Indian, things were looking a bit different in the war-devastated country ${ }^{8}$.

Warfare for a number of intensive months in 1941-42, over three years of Japanese occupation confronted by a Communist-led guerrilla movement and the political and economic pains of the re-establishment of British rule after August 1945 meant deep scars for the country. Over half a million Chinese had joined their fellow countrymen in a squatting existence in the fringe of the jungles, scraping a meagre existence from subsistence agriculture $^{9}$. In the small cities and villages close to the rubber plantations and tin mines hundreds of thousands of Malays and Chinese looked for jobs and the restarting of production brought the same meagre wages and colonialist attitudes from the English owners and managers of the estates ${ }^{10}$. In the larger cities, the Malay and Chinese middle classes were

\footnotetext{
${ }^{3}$ Noel Barber, The War of the Running Dogs. How Malaya Defeated the Communist Guerrillas 1948-60, Glasgow: Fontana, 1972, 12.

${ }^{4}$ Gregory Blaxland, The Regiments Depart. A History of the British Army, 1945-1970, London: William Kimber, 1971, 73.

${ }^{5}$ E.D. Smith, Counter-insurgency Operations: Malaya and Borneo, London: Ian Allan, 1985, 5.

${ }^{6}$ Julian Paget, Counter-Insurgency Campaigning, London: Faber and Faber, 1967, 45.

${ }^{7}$ Rubber for instance was, after the war, more important than manufacturing in the exports of the British Empire, John Newsinger, British Counterinsurgency. From Palestine to Northern Ireland, Houndmills: Palgrave, 2002, 41; for the role of rubber and tin role before the war see M.C. Rickfels, Bruce Lockhart, Albert Lau, Portia Reyes, Maitrii Aung-Thwin, A New History of Southeast Asia, Houndmills: Palgrave, $2010,242$.

${ }^{8}$ For statistics on population see Richard Clutterbuck, Guerrillas and Terrorists, London: Faber and Faber, 1977, 37. Others mention for $194141 \%$ Malay to 43\% Chinese, M.C. Rickfels et. al., A New History of Southeast Asia, 327. Many of the Chinese had intermarried with Malay families, adopting Islam and all but forgetting their language.

${ }^{9}$ The Chinese massive immigration to Malaya started after the British development of the port of Singapore in 1818 and, later in the $19^{\text {th }}$ century, fuelled by the demand for labour in the tin and rubber industries in the Western part of the Peninsula, Sam C. Sarkesian, Unconventional Conflicts in a New Security Era. Lessons from Malaya and Vietnam, Westport: Greenwood, 1993, 60-61.

${ }^{10}$ For living and working in British Malaya see Rashid Maidin, The Memoirs of Rashid Maidin. For the attitudes of the British see the memoirs of Robert Thompson, Make for the Hills. Memories of Far Eastern Wars, London: Leo Cooper, 1989.
} 
expecting a change in their favour, with a new power-sharing agreement with the British and some were beginning to nurture dreams of independence ${ }^{11}$. In the jungles covering the mountains which form the central spine of the peninsula, tens of thousands of aborigines continued their traditional ways of life, uninterrupted for centuries and millennia except for the brief period during the war when they entered a reciprocal-help relationship with the antiJapanese guerrillas $^{12}$.

In this context the return of the British proved a challenging experience both for the authorities and the colonised peoples. The princely states of Malaya and the crown colonies were initially ruled by the British Military Administration, until the new civilian High Commissioner would negotiate with the elite a new power arrangement for the country ${ }^{13}$, in a general colonial strategy which envisaged a coordinated move towards autonomy and, after many decades, independence on British terms. But the post-war re-occupation seemed to bring a determined effort by the British to bring the Malay states in a more concentrated colonial setting and the local population saw in this framework the Malayan Union, the first proposal for a political functioning of the country ${ }^{14}$. To form the Malayan Union, which called for a vast reduction of the power of the princes, reduced to the positions of religious rulers and political figureheads, extreme pressure was applied on the sultans or regents of the Malaysian states, usually by being accused of collaboration with the Japanese. Any pretence of their British Residents or Advisors, in place for a long time, having just consultative attributions was dropped ${ }^{15}$. In addition to diminishing the power of the local rulers, one of the most contentious points of the Malayan Union was the near-universal enfranchisement of the Chinese, many of whom were seen by the ethnic Malays as outsiders, economic migrants recently arrived in the country to reap the benefits but unwilling to share its culture ${ }^{16}$.

To counteract it, the first major local political force (UMNO) was created, under the leadership of a local nobleman from Johore, Dato On bin Jafar. It became instrumental in making the British negotiate in July 1946 a new form of political framework for the country, which led to the formation of the Federation of Malaya on 1 February 1948. Citizenship was restricted to those who resided in Malaya for at least 15 of the previous 25 years, issued a declaration of permanent settlement and could speak Malay or English. Less than $10 \%$ of the Chinese qualified for automatic citizenship ${ }^{17}$.

\footnotetext{
${ }^{11}$ See for that Khong Kim Hoong, Merdeka! British Rule and the Struggle for Independence in Malaya, $1945-$ 1957, Kuala Lumpur: Institute for Social Analysis, 1984.

12 John D. Leary, Violence and the Dream People. The Orang Asli in the Malayan Emergency 1948-1960, Athens: Ohio University Center for International Studies, 1995.

${ }^{13}$ This military administration lasted from September 1945 until the formation of the Malayan Union on 1 April 1946, A.J. Stockwell, "Southeast Asia in War and Peace: The End of European Colonial Empires" in Nicholas Tarling (ed.), The Cambridge History of Southeast Asia, Vol. II The nineteenth and twentieth centuries, Singapore: Cambridge University Press, 1992, 353.

${ }^{14}$ M.C. Rickfels et. al., A New History of Southeast Asia, 329.

${ }^{15}$ Barbara Watson Andaya, Leonard Y. Andaya, A History of Malaysia, Honolulu: University of Hawai`i Press, 2001, 266.

${ }^{16}$ Sam C. Sarkesian, Unconventional Conflicts in a New Security Era, 58.

17 Barbara Watson Andaya, Leonard Y. Andaya, A History of Malaysia, 268; M.C. Rickfels et. al., A New History of Southeast Asia, 329; A.J. Stockwell, "Southeast Asia in War and Peace", 354.
} 
This Malayan political mobilization prompted the Chinese and Indian communities to join the political struggle in early 1946. The British intelligence was quick to pick this up and summarized it as such: "Malays and Chinese who possess a high spirit of nationalism are working against each other" ${ }^{\prime 18}$. Soon overshadowing other Chinese political groupings, the local Chinese communists became the backbone of resistance to the Federation, in a broader social and political struggle. Their main initial approach was using the trade unions in the political struggle, especially the General Labour Union, 263000 members strong. Indeed, the Malayan Communist Party (MCP) dominated the trade union's confederation in 1946-1947, which was used in a framework of legal political struggle both against the economic elite and the political arrangement which excluded most of the Chinese from effective participation in Malayan social life ${ }^{19}$.

This radicalization was obviously seen with some degree of regret by the British, which throughout the war held good contacts with the Chinese communists which formed the largest element of the Malayan's Peoples Anti-Japanese Army (MPAJA), the guerrilla front harassing Tokyo's forces in that part of the world. British liaison officers and afterwards the members of commando unit Force 136 worked with the communists, provided them with weapons, got to know some of their emerging leaders such as the very young Chin Peng and eventually even signed an agreement with the MPAJA putting it under the orders of South East Asia Allied Command ${ }^{20}$. The Communist acquiescence and cooperation had been instrumental in the relatively swift restoration of British authority in the colony. The stabilization of South East Asia in the first years of what soon was called the Cold War was important on many economic and strategic levels and in no small measure served to reassure the pre-eminence of the British as the most important ally of Washington in the area ${ }^{21}$.

In retrospect, thinking about the violent reaction of the Vietnamese communists to the French return to Indochina, MCP's reaction was both a blessing for London and a puzzle for everyone else. But MCP's failure to launch an aggressive anti-British campaign had a few explanations, which can also highlight some of its features as a guerrilla force. First, and perhaps foremost as a direct explanation, the leadership of the MCP was during the war and until early in 1947 in the hands of Lai Tek, who had been a British agent for a long time before the war ${ }^{22}$. Indeed, Lai Tek had begun betraying his party comrades soon after he was recruited in the early 1930s by French intelligence in Indochina. Passed over to the British after his cover was blown and moving from Saigon to Singapore, he quickly rose to power positions during the party, where he successfully advocated a pacifist and legalist attitude. During the war he became a double-agent, preserving his life and luxurious lifestyle by

\footnotetext{
${ }^{18}$ HQ Malaya Command Weekly Intelligence reviews no 30-32, 31 May - 22 June 1946 CO537/1581 nos. 14, 15 and 16 in A.J. Stockwell (ed.), Malaya, London: HMSO, 1995, Part I The Malayan Union Experiment 1942$1948,242$.

19 Khong Kim Hoong, Merdeka!, 122-123; Barbara Watson Andaya, Leonard Y. Andaya, A History of Malaysia, 270.

${ }^{20}$ Geoffrey Fairbarn, Revolutionary Guerrilla Warfare. The Countryside Version, Harmondsworth: Penguin, 1974, 125-126.

${ }^{21}$ Nicholas Tarling, Britain, Southeast Asia and the Onset of the Cold War, 1945-1950, Singapore: Cambridge University Press, 1998, 309, 313.

${ }^{22}$ John Newsinger, British Counterinsurgency, 36.
} 
helping the Japanese to deliver a devastating blow to the MPAJA, by tipping them to the location of a leadership conference he had organized but where he had conveniently failed to show $u^{23}$. Through the massacre of his peers his position inside the party had been consolidated and he seems to have never been questioned or criticized until the moment in February 1947 when he absconded with the Party funds, leaving it in disarray ${ }^{24}$.

Secondly, the subsequent generation of MCP leaders was extremely young and inexperienced except in the ways of guerrilla warfare. Their cooperation with the British military during the war may have initially softened their attitudes - the next leader of the party himself, Chin Peng, had been awarded the Order of the British Empire and decorated by Admiral Louis Mountbatten personally ${ }^{25}$. The MPAJA units had marched together with the British in victory parades throughout Malaya in the fall of 1945 and - in a move that can be blamed again on Lai Tek, had agreed to its own disbandment and many of its individual members had surrendered their weapons for cash payments ${ }^{26}$.

The Chinese communists in Malaya were not only young and inexperienced, but unlike almost any other communists around the world had virtually no direct and personal links with the centres of Marxist-Leninist thought and practice. Unlike their Northern Vietnamese comrades, educated in the leftist circles of Paris and enjoying direct help from Mao Zedong, the MCP leaders were isolated ${ }^{27}$. To highlight this no better example can be given that the theory that the Moscow-issued order for the beginning of the insurgency had been relayed in February 1948 during a stop-over in Kuala Lumpur by the Australian communist Lawrence Sharkey, returning from a conference in Calcutta. While no documentary support had ever been found in favour of this theory and most historians reject it, it serves to highlight the isolation of the MCP, which could not even send its own people to Calcutta. In effect, Malaya was such a peripheral theatre from Moscow's perspective that Stalin was uninterested and perhaps unable to send any help or issue any guidance both before and after $1948^{28}$.

Thirdly, the MCP was cut-off from any outside help not only by its leadership's lack of contacts and the lack of interest in its activities from Moscow, but also by the geographic features of the country which played a significant role in its strategy and in its nearlyunavoidable defeat. Indeed, Malaya is a long peninsula no more than 400 miles long and 200 miles wide, with extremely long coastlines easy to patrol by the Royal Navy. Its only

\footnotetext{
${ }^{23}$ Richard Clutterbuck, The Long Long War. Counterinsurgency in Malaya and Vietnam, New York: Frederick A. Praeger, 1966, 17, 29.

${ }^{24}$ Lai Tek's fate is shrouded in mystery, but nearly certainly Thai communists caught up with him in Bangkok and put an end to his life, Richard J. Aldrich, The Hidden Hand. Britain, America, and Cold War Secret Intelligence, Woodstock: The Overlok Press, 2002, 496.

${ }^{25}$ Julian Paget, Counter-Insurgency Campaigning, 43.

${ }^{26}$ Each man who did this was paid $350 \$$ and 6000 out of 7000 took up the offer James E. Dougherty, "The Guerrilla War in Malaya" in Franklin Mark Osanka (ed.), Modern Guerrilla Warfare. Fighting Communist Guerrilla Movements, 1941-1961, New York: The Free Press of Glencoe, 1964, 300.

${ }^{27}$ Anthony Short, "The Malayan Emergency" in Ronald Haycock (ed.), Regular Armies and Insurgency, London: Croom Helm, 1979, 65.

${ }^{28}$ T.N. Harper, The End of Empire and the Making of Malaya, Cambridge: Cambridge University Press, 1999, 152; Peter Lowe, Contending with Nationalism and Communism. British Policy towards Southeast Asia, 194565, Houndmills: Palgrave, 2009, 44.
} 
neighbour, Thailand, mostly behaved like a British ally and definitely would not allow any help to trickle down to the $\mathrm{MCP}^{29}$. Most of the six million inhabitants were concentrated in the great city of Singapore and on the western side of the peninsula in a narrow strip of a few dozen miles where the rubber plantations and the tin mines were situated, leaving the eastern side scarcely populated ${ }^{30}$. The "proper" guerrilla country was the mountainous, jungle covered interior, which could provide shelter and rest, but was hard to navigate and dangers such as falling trees, leeches and lice kept those living in it constantly on the edge ${ }^{31}$. Moreover, the soil of the country, both in the jungle and on its fringes, was poor for agriculture. Already before the insurgency started getting food was a problem, Malaya producing only a third of its food consumption ${ }^{32}$. Large groups of people could not survive on game and fruits in the jungle, so outside support was crucial for any guerrilla force operating outside the western areas of the peninsula.

To this one needs to add a fundamental ethnic reality. The MCP was and remained an overwhelmingly Chinese manned and dominated party. While some Malay joined it, eventually being able to form during the Emergency a full Malay communist regiment and some prominent Indians were among its members, the Chinese dominance was both a blessing and a curse, as it insured the cooperation of the many poor Chinese and the hostility of the vast number of Malays ${ }^{33}$.

Despite all of these considerations, the MCP chose the path of violent confrontation after the disappearance of Lai Tek. The Malayan Federation project could be seen as a tactic to deny for a long time independence of the country; it also enshrined, from the communists' perspective the dominating position of the British planters and mine owners and managers, in an alliance with the Malay and Chinese bourgeoisie; while it was also making life more difficult for the lowly Chinese. These political problems were overlapping a deep economic chasm for the lower classes in Malaya, with low wages, unsecure jobs and the continuation of a rural crisis which had begun during the Great Depression and never stopped. The rural crisis itself was the root cause for the explosion in the numbers of the Chinese squatters scrapping a meagre existence from a low-quality soil. What the British colonizers and their academic defenders considered "a primitive and destructive mode of agriculture" 34 , the MCP saw as the terrible effect of capitalist and imperialist rule and in need of immediate correction. Thus, starting with late 1947 and through the first months of 1948 the communists of Malaya pursued a path of confrontation, starting with mass strikes and union actions and escalating into armed attacks as the summer of $1948 \mathrm{set}^{35}$.

\footnotetext{
${ }^{29}$ Robert Thompson, Defeating Communist Insurgency. Experiences from Malaya and Vietnam, London: Chatto \& Windus, 1966, 19.

${ }^{30}$ Sam C. Sarkesian, Unconventional Conflicts in a New Security Era, 63.

${ }^{31}$ Fong Chong Pik.

${ }^{32}$ On the food problem and generally the social crisis that was the basis of the rebellion see T.N. Harper, The End of Empire, 94-95, 97.

${ }_{33}$ Martin Thomas, Bob Moore, L.J. Butler, Crises of Empire. Decolonization and Europe`s Imperial States, 1918-1975, London: Hodder Education, 2008, 63.

${ }^{34}$ Geoffrey Fairbarn, Revolutionary Guerrilla Warfare, 144.

${ }^{35}$ Before the Emergency started in June 1948, the country was affected by large, Communist-inspired strikes and labour unions protests. Police violence was considerable; in a confrontation on 1 June on a Johore estate the
} 
Confronting all of this, the British authorities could rely on the support of many local social and political power structures, as well as the resources the metropolis could send to defend the richest of its foreign possessions after the loss of India in 1947. Unwavering throughout the crisis, the British planters, tin mine owners, engineers, administrators, police officers and government workers offered their time, money and efforts to the suppression of the rebellion ${ }^{36}$. In a crushing majority the ethnic-Malay population rejected the communist appeal and joined the counterinsurgency efforts, especially after the speeding up of the independence-granting process ${ }^{37}$. Obviously, the political and economic elite, Malay and Chinese alike abhorred any communist project and lent all its support to the government ${ }^{38}$.

While these external aides were instrumental in the general COIN approach, the internal strengths of the British authorities should not be neglected. First, the experience of colonial warfare was vast ${ }^{39}$, and despite the arguments of some authors that jungle-fighting ability was lost in the three years passed from 1945 to $1948^{40}$ this can hardly be believed. Anyway, the government could - and did eventually - call upon imperial forces whose natural setting was the jungle, most importantly the Iban trackers from Borneo, the Fijian Regiment and the Kenya-based King's African Rifles; the Gurkha brigades also adapted extremely fast to the realities of warfare in the Malayan interior.

Secondly, while at the beginning of the Emergency the effective number of troops that the British could field against the MCP was roughly the same as that of the rebels (around $8000)^{41}$, the government could call on massive reinforcements from the United Kingdom and Hong Kong and could rely on the limited, but solid help from Australia. Human resources, most importantly police and intelligence specialists with experience in Palestine and India were also available for the COIN strategy.

Thirdly, the government had the financial ability to vastly increase the numbers of policemen and the size of paramilitary units in the country and improve the quality of their armament and transport ${ }^{42}$, while simultaneously carrying a systematic program of uprooting

police killed eight workers, see Karl Hack, Defence and Decolonisation in Southeast Asia. Britain, Malaya and Singapore 1941-1968, Richmond: Curzon, 2001, 117. MCP reaction was swift, already in the first half of June 1948 there had been 19 murders and attempted murders attributed to the communists, see Malayan Security Service Political Intelligence Journal CO537/3753 no 35, 15 August 1948 in A.J. Stockwell (ed.), Malaya, Part II, The Communist Insurrection 1948-1953, 64-65.

${ }^{36}$ Martin Shipway, Decolonization and its Impact. A Comparative Approach to the End of Colonial Empires, Singapore: Blackwell, 2008.

37 The British tapped skilfully in anti-Chinese feelings caused by the retribution of the anti-Japanese guerrillas (the Chinese and MCP-dominated-MPAJA) in 1945 against those perceived as collaborators, Donald M. Nonini, British Colonial Rule and the Resistance of the Malay Peasantry, 1900-1957, New Haven: Yale University Southeast Asia Studies, 1992, 109-110.

${ }^{38}$ These groups were carefully identified by British intelligence early on during the Emergency, Letter from $\mathrm{H}$. Gurney to T. Lloyd CO537/3758 no 19, 8 October 1948 in A.J. Stockwell (ed.), Malaya, Part II.

${ }^{39}$ Charles Townshend, Britain's Civil Wars. Counterinsurgency in the Twentieth Century, London: Faber and Faber, 1986, 14.

${ }^{40}$ Daniel Marston, "Lost and Found in the Jungle. The Indian and British Army jungle warfare doctrines for Burma, 1943-45, and the Malayan Emergency, 1948-60" in Hew Strachan (ed.), Big Wars and Small Wars. The British army and the lessons of war in the twentieth century, New York: Routledge, 2006, 97.

${ }^{41}$ Anthony Short, The Communist Insurrection in Malaya 1948-1960, London: Frederick Muller, 1975, 114.

42 A policy with questionable results, see Eric Jardine, "The Influence of Military Materiel on Tactics and Strategy in Counterinsurgency: a Case of British Malaya" in Defence Studies, Vol. 11, No. 4 (2011), 636-656. 
the support the communists could get from the Chinese squatters. Indeed, one can argue that the crisis "entailed a far-reaching militarisation of Malayan society and made the colonial state an authoritative presence in the lives of many Malayans for the first time" ${ }^{\text {"4 }}$. In these regards, the beginning of the Korean War in the summer of 1950 had a very beneficial effect for the government of Malaya, driving the prices for rubber and tin to record highs. The ability to spend more on security forces was thus vastly increased. This also enabled the planters and mine owners to spend more on private security, thus helping the COIN campaign $^{44}$.

One can roughly distinguish three main phases of the Emergency. For the first two years of the Emergency the government constantly increased its strength and pursued a strategy of denying the communists the possibility of occupying safe bases in inhabited areas, while in the same time suffering many attacks and failing in most attempts of crushing the insurgency through large-scale conventional military operations ${ }^{45}$. In the second phase, roughly corresponding with the period between the formulation and adoption of the "Briggs Plan" in the summer of 1950 and 1955, the British achieved victory in the field through a mixture of a vast population control strategy, increased intelligence ability and a better and more flexible operational approach. In the third phase, from 1955 to 1960, the British and the newly independent (from 1957) government from Kuala Lumpur focused on propaganda, informative penetration and counter-gangs to mop-up the remainder of the communist fighters, until their final retreat into Thailand.

The analysis that follows is centred on population control tactics, intelligence gathering and its use, the military operations and the destruction of the rebel groups, with a chronological approach taking a step back and being used only when describing a transformational process.

\section{Population control}

Traditional warfare between organized armed groups, be they states or other entities, supposed that victory is achieved either through a battle or series of battles which would render one of the opponents unable to fight or through control of a number of strategic locations or a vast area of the disputed lands. In asymmetric conflict victory in battle rarely brings total victory, because guerrillas almost never engage their full strength against the government's forces; similarly, even full control of the entire disputed territory does not necessarily translate into victory, as the unidentified rebels could easily blend into the

\footnotetext{
${ }^{43}$ T.N. Harper, The End of Empire, 150.

${ }^{44}$ Dunlop - one of the major corporate owners of plantations had 70 armoured cars and was hiring European security officers, Richard Stubbs, Hearts and Minds in Guerrilla Warfare. The Malayan Emergency 1948-1960, Singapore: Oxford University Press, 1989, 107, 112.

${ }^{45}$ Robert Thompson, Defeating Communist Insurgency, 16.
} 
population, like fishes in the sea in Maoist parlance, and restart armed action as soon as the authorities`vigilance diminishes ${ }^{46}$.

Population control, physical and psychological replaces territorial control in COIN. To achieve victory the government needs to organize the favourable groups, to cultivate the neutral, to try to placate the mildly hostile, while deporting or isolating and re-educating those groups deemed to be the most dangerous. Moreover, the government needs to portray itself as a better solution for its citizens, both by providing a long-term solution to the root problems of the rebellion, be they social, economic or political and by being seen to act in the framework of the rule of the law ${ }^{47}$.

In Malaya this was, in a sense, the big key to eventual military and political victory over the communist guerrillas. While military action played a very important role, initially by preventing the rebels from acquiring bases, then by forcing them to operate in smaller and smaller groups and eventually by mopping up the remaining groups, it was large-scale actions involving extensive deportations to China, the massive "resettlement" program involving almost half of the two million Chinese living in Malaya and the propaganda effort which accounted for complete victory ${ }^{48}$. Throughout the latter stages of the Malayan Emergency and in the subsequent decades, in memoirs and academic monographs this effort has been called, rather benignly, a campaign for the "hearts and minds" of the population, an expression that made a great career, still flourishing in contemporary field manuals and COIN practice. The following pages argue that what happened can be better interpreted as a brutal, often ruthless and sometimes murderous campaign targeting a specific ethnicity and those allied with it. Total control over the bodies and even the minds of possible opponents was what the government aimed for and in a general sense this was achieved ${ }^{49}$.

It must be said from the beginning that the British military and civilian authorities made sure that they worked in a legal framework, or they made efforts to create the legal framework in which their actions would be justifiable. Having done so permitted them many things. First, it allowed them to present an image of legality and legitimacy that could be used for propaganda purposes. This image was so strong that decades afterwards some academics were still able to defend the British record in colonial counterinsurgency and even present it as a model. Secondly, it allowed their personnel to operate with impunity. In this regard, the careful selection of documents for preservation and the destruction of some files before their shipment to the archives in the United Kingdom after the proclamation of Malaya's

\footnotetext{
${ }^{46}$ Mao Tse-Tung, On Guerrilla Warfare, New York: Praeger, 1961; Ian F. W. Beckett, Modern Insurgencies and Counter-insurgencies. Guerrillas and their Opponents since 1750, London: Routledge, 2001, 70-76.

${ }^{47}$ This is a distillation of some of the principles of COIN identified by Robert Thompson, Defeating Communist Insurgency, 50-58.

${ }^{48}$ This argument was mostly defended by Karl Hack, see his articles "British Intelligence and CounterInsurgency in the Era of Decolonization: The Example of Malaya" in Intelligence and National Security, Vol. 14, No. 2 (1999), 124-155 and "The Malayan Emergency as Counter-Insurgency Paradigm", Journal of Strategic Studies, 32: 3 (2009), 383 - 414.

${ }^{49}$ A similar interpretation can be found in Huw Bennett, "'A very salutary effect': The Counter-Terror Strategy in the Early Malayan Emergency, June 1948 to December 1949” in Journal of Strategic Studies, 32: 3 (2009), $415-444$
} 
independence in 1957 also played an important part ${ }^{50}$. Thirdly, it permitted a swift and decisive treatment of all groups and individuals deemed as security threats, while assuaging their officers and troops that everything is ethical and normal ${ }^{51}$.

One of the most important legal perspectives was to consider the United Nations' Universal Declaration of Human Rights as a non-binding document and to also label the communist insurgents initially as common-law bandits and then as terrorists. Failing to recognize the crisis as a civil war permitted the authorities to ignore the provisions of the Geneva conventions for the treatment of prisoners of war, by denying the status of legal combatants to their enemies ${ }^{52}$. The Emergency Regulations that were adopted therefore legalised deportations ${ }^{53}$, resettlement, and destruction of property. Even more poignantly, they suspended habeas corpus, allowing for indefinite detention without trial of suspected sympathizers of the MCP; the most ruthless provision, applied in a few hundred cases, called for mandatory death penalty for anyone caught in possession of an illegal firearm ${ }^{54}$. The judges were forced to issue this punishment, making their independence a theoretical notion $^{55}$.

In the aftermath of the assassination of three British citizens on 16 June 1948 and the subsequent proclamation of Emergency throughout Malaya, the British authorities moved swiftly against those identified by the civilian intelligence agencies as the most dangerous in the Chinese community. An immediate program of deportations, justified mostly by their lack of Malayan citizenship, was started, with whole families removed from their homes and deported to mainland China ${ }^{56}$. After a lull in the program caused by the victory of the communists in the Chinese Civil War in September 1949, the deportations were resumed, as Mao Zedong was willing to show the world that the new regime is a home to all oppressed ${ }^{57}$. In total, 12000 Chinese were deported in the course of the Emergency. As the government had moved extremely fast, both immediately before and immediately after against the known Communist and trade union elites in Malaya's main cities (especially Singapore, Malacca and Kuala Lumpur), this effectively deprived the MCP from an urban arm, constraining it to a pure rural and jungle-based approach. Although anti-colonial and leftist riots in the big cities

\footnotetext{
${ }^{50}$ Ian Cobain, Owen Bowcott and Richard Norton-Taylor, "Britain destroyed records of colonial crimes", The Guardian, 18 April 2012, http://www.guardian.co.uk/uk/2012/apr/18/britain-destroyed-records-colonial-crimes last consulted on 19 October 2012.

${ }^{51}$ The legal aspects of the British approach to counterinsurgency in the late colonial era, with special references to Malaya have been masterfully analysed in David French, The British Way in Counter-Insurgency, 1945-1967, Oxford: Oxford University Press, 2011. The above interpretation in these matters owes a lot to this work.

${ }^{52}$ See for different perspectives on the topic Charles Townshend, Britain's Civil Wars; John Newsinger, British Counterinsurgency; Thomas R. Mockaitis, British Counterinsurgency, 1919-1960, London: Macmillan, 1990.

${ }^{53}$ For instance, according to Regulation 17D the High Commissioner could order the arrest of whole villages proved to aid the guerrillas; in the first nine months of 1949 was used 16 times with 6000 people detained, Julian Paget, Counter-Insurgency Campaigning, 54.

${ }^{54}$ Most prominent case was that of one of the few Indians allied with the communists, S.A. Ganapathy, a former president of the Pan-Malayan Federation of Trade Unions, who was hanged by the British authorities on 4 May 1949 for illegally possessing a revolver, Anthony Short, The Communist Insurrection in Malaya 1948-1960, 210.

${ }_{55}^{55}$ Richard Clutterbuck, The Long Long War, 39.

${ }^{56}$ Whole villages were sometimes deported, Karl Hack, "The Malayan Emergency as Counter-Insurgency Paradigm".

${ }^{57}$ Martin Shipway, Decolonization and its Impact, 169.
} 
were erupting as late as 1957 , they were never serious threats and the simple shipment and of Gurkha battalions from the mainland to Singapore and their parading through the streets quelled the most serious disturbances ${ }^{58}$.

Vast numbers of those arrested were not deported, but instead were held for years without trial in what were effectively internment camps. Deprived from contact with their families, thousands of suspected collaborators and sympathizers of the rebels lived in makeshift barracks and huts, guarded by Malay troops officered by British personnel. Hard labour with very little pay was the norm in these camps, though the detainees had time to discuss their political options, either remaining steadfast or choosing to repent ${ }^{59}$. Some, very few, were able to escape without getting shot and joined the rebels. Drawing from the inmates in these camps, a re-education centre was created and its success, at least as reported by those running it, was notable ${ }^{60}$.

The most notorious aspect of the population control policies in Malaya was the vast program of internal deportation, called in official documents and subsequent academic literature "resettlement". The British colonial government realized soon after initial military operations failed to destroy the insurgents that one of its most important strategies needs to be the separation of the rebels from their sources of support. As the MCP was 90\% Chinese and drew its strength from the poor elements of this ethnic group of the peninsula, the authorities resolved to target the group in order to destroy the Min Yuen (People's Movement), the communist logistical and intelligence network operating in its midst ${ }^{61}$.

Internal deportation was identified early on as the best way to deal with the rebel's support network ${ }^{62}$. Indeed, programs of moving the rural ethnic Chinese in governmentcontrolled communities started in 1949 under the High Commissioner Sir Henry Gurney ${ }^{63}$, but were brought to their full intensity under High Commissioner and Director of Operations General Sir Gerald Templer, who ruled Malaya with proconsul powers from 1952 to 1954. It was during this latter period when the program was fully completed and the results became apparent. Overall, it involved the destruction of the squatters' way of life, as all of them half a million people - were forced to move from their villages (kampongs) in the jungle's fringes to a number of "New Villages" in areas closer to the coast and to the main plantations and tin mines. In addition to that, another half a million Chinese already working on the

\footnotetext{
${ }^{58}$ Richard Clutterbuck, The Long Long War, 30.

${ }^{59}$ Rashid Maidin, The Memoirs of Rashid Maidin.

${ }^{60}$ The centre was opened at Taiping in the state of Perak in November 1949 and it processed (re-educated) 1280 Chinese until March 1953 of which only 8 "relapsed" into Communism, Thomas R. Mockaitis, British Counterinsurgency, 1919-1960, 114.

${ }^{61}$ While this was realised fairly early, the crystallization of the policy was in the proposals issued by LieutenantGeneral Harold Briggs in the spring of 1950. The outline of his strategy called for: dominating the populated area, securing them and use them as information sources; breaking up the Min Yuen in the populated areas; therefore to isolate the bandits from the food and information supply organization; destroying the bandits by forcing them to attack the security forces in the secured territory, see "The Briggs Plan" CAB 21/1681 MAL C(50)23, Appendix, 24 May 1950 in A.J. Stockwell (ed.), Malaya, Part II, 217.

${ }^{62}$ Telegram from Henry Gurney to Creech Jones CO717/167/52849/2/1948, ff 108-110, 25 October 1948 in A.J. Stockwell (ed.), Malaya, Part II, 77-79.

${ }^{63}$ Cabinet memorandum by Creech Jones CAB 129/33/1, CP (49) 52, 5 March 1949 in A.J. Stockwell (ed.), Malaya, Part II, 118.
} 
plantations and tin mines were regrouped from their initial lodgings to government controlled and policed settlements ${ }^{64}$.

The process of deportation itself was painful enough. Government troops usually arrived in a village and gave its inhabitants a few hours to gather their belongings after which they were herded in trucks and moved to their new places of residence. The troops then burned the village and destroyed the crops. To assuage their feelings, European soldiers and officers were insured by their superiors that the squatters were just nomads and the kampongs just temporary shelters ${ }^{65}$. Obviously, the Chinese peasants were not able to collect all of their belongings and they were seldom compensated for their losses ${ }^{66}$.

The reality of "New Villages" has been portrayed by their proponents as clean, organized and safe communities offering their inhabitants security from attacks, good roads, schools and medical assistance ${ }^{67}$. Obviously this is true in a certain regard, though in the initial phases of the resettlement programs those who lived in the new communities found very little in terms of hygiene and education, at least until the government got organized and financed this program accordingly. The Chinese families were indeed allotted a small plot to build a hut and grow some crops and a sum to support them for their first five months ${ }^{68}$. They were also promised titles of property to the lands they were going to cultivate ${ }^{69}$. But from the perspective of the former squatters the reality of their new homes must have been strikingly different. Undergoing the trauma of having been moved from their homes, they found themselves in new, unknown surroundings, confined in what were effectively camps surrounded by barbwire, some with night perimeter lighting. Obviously, night moves were prohibited. Moreover, the villages were for many years guarded by police units raised almost entirely from the ethnic Malays, who were not necessarily displaying a very endearing attitude towards the Chinese ${ }^{70}$. It took a long time until the effect of government propaganda was positive and the authorities were able to replace the Malay policemen with Chinese Home Guards insuring the security of the New Villages ${ }^{71}$.

Understanding that a main priority for destroying Min Yuen was the classification of all possible supporters, the government started issuing identification cards to all of the inhabitants of the new settlements, thus tracking their moves and connections. The identity

\footnotetext{
${ }^{64}$ Numbers of the deported reached 423000 for the Chinese squatters relocated in 410 new villages and -116 about 650000 mine and estate workers settled in wired-in villages. They accounted for about half of the entire Chinese community in Malaya, David French, Army, Empire, and Cold War. The British Army and Military Policy, 1945-1971, Oxford: Oxford University Press, 2012, 115.

${ }^{65} \mathrm{ibid}$.

${ }^{66}$ As one of the classic analysts of the Emergency said: "putting the squatter inside a fence, and quickly, was all that seemed to matter", Richard Stubbs, Hearts and Minds in Guerrilla Warfare, 103.

${ }^{67}$ Robert Thompson, Defeating Communist Insurgency, 121; James E. Dougherty, "The Guerrilla War in Malaya", 303. As late as 2010 some could write: "The Chinse villages were not constructed as concentration or labour camps, but as politically engaged and progressive communities", David H. Ucko, "The Malayan Emergency: The Legacy and Relevance of a Counter-Insurgency Success Story" in Defence Studies, Vol. 10, No. 1-2 (2010), 26.

${ }^{68}$ Julian Paget, Counter-Insurgency Campaigning, 59.

${ }^{69}$ Thomas R. Mockaitis, British Counterinsurgency, 1919-1960, 116.

${ }^{70}$ Richard Clutterbuck, Guerrillas and Terrorists, 39; Richard Clutterbuck, The Long Long War, 40.

${ }^{71}$ John Newsinger, British Counterinsurgency, 41.
} 
cards comprised personal details, a photograph and fingerprint. By identity controls when leaving or entering the village and random controls on the roads, any suspect individual or move could be thus detected and brought to the attention of intelligence agencies ${ }^{72}$. The MCP understood this soon enough and it strove to destroy the identification cards of anyone they encountered, thus mostly insuring that the civilians went through a harrowing bureaucratic process of having to renew their cards.

Possibly the most efficient COIN policy which was permitted by the resettlement program was strict food control and rationing. As noted before, Malayan soil cannot easily support vast numbers of people and the jungle itself, where guerrillas were forced to operate soon after the beginning of the crisis, is even less able to provide food to large numbers of people dwelling in it, especially if they are not accustomed to a hunters-gatherers lifestyle. By destroying the squatter settlements the British cut the lifeline they could give to the communist guerrillas $^{73}$. To insure that food would not even trickle from the New Villages, strict food controls were implemented at the entrance of the settlements. The Chinese workers, marched daily to their new working places, rubber plantations, tin mines or agricultural plots, were subjected to systematic searches and controls for food. Workers were prevented for having any food for lunch; when food was issued to the inhabitants of the villages, it usually consisted of fried rice - which in the humid climate became uneatable within two days ${ }^{74}$.

One should add that it was not only the Chinese who were subjected to the resettlement policies. In the early phases of the conflict, until it was realized that they can be turned to the government's side with better effect if left in the jungles, substantial numbers of Malayan aborigines were also moved to New Villages. Unaccustomed to a sedentary lifestyle and confinement to enclosed, insalubrious places, the death toll among them was larger than in the ranks of the squatters ${ }^{75}$.

Resettlement was not, obviously, an easy walk in the park for the military authorities. There were serious instances when the former squatters refused to comply with the government guidance in the new communities, either by continuing their support to the insurgents, either by refusing to cooperate with the police and intelligence agencies in providing information about the rebels. In some cases, the reaction of the authorities involved collective punishments over whole villages. General Gerald Templer, who otherwise coined the benign "hearts and minds" slogan for his policies, personally carried out such punishments in Tanjong Malim ${ }^{76}$ and other recalcitrant communities. Put under arrest and an early curfew, the inhabitants and their elders were publicly scolded, fined and had their food rations reduced $^{77}$. More often than not, collective punishments eventually produced

\footnotetext{
${ }^{72}$ Richard Clutterbuck, The Long Long War, 38.

${ }^{73}$ Peter Lowe, Contending with Nationalism and Communism, 46.

${ }^{74}$ The extremely detailed regulations concerning the conduct of searches can be found in Director of Operations, Malaya, The Conduct of Anti-Terrorist Operations in Malaya, $3^{\text {rd }}$ edition, 1958.

75 John D. Leary, Violence and the Dream People.

${ }^{76}$ Charles Townshend, Britain's Civil Wars, 160.

77 On collective punishment in Tanjong Malim, Pekan Jabi and Permatang Tinggi see the letter from Oliver Lyttleton to Grimond CO1022/56 no 35, 10 December 1952 in A.J. Stockwell (ed.), Malaya, Part II, 424-425.
} 
compliance, although there were voices that doubted their efficiency ${ }^{78}$. In a few cases the reaction could be far more brutal. The most notorious incident was at the New Village of Batang Kali, where troops of the $2^{\text {nd }}$ Scots Guards shot and killed under the pretence of an attempted escape 20 unarmed but recalcitrant Chinese villagers, with the whole incident deemed legal by the Attorney General of Malaya ${ }^{79}$.

Overall, the population control policies were brutal and effective ${ }^{80}$. They broke the connections between the MCP and their main source of support, severing intelligence and food supplies for the guerrillas. They allowed government easy access to a population that could be coerced or convinced through different incentives to side with it, while also permitting the development of an information network that was eventually used to eliminate the Min Yuen. It also helped that the policy was combined with a serious propaganda effort aimed at civilians, in which the British-inspired and coordinated Malayan Chinese Association played a great part $^{81}$. This psychological warfare component was aiming to show that the communists were even more brutal and violent than the authorities and that the established rule, coupled with promises of land and citizenship in an independent Malaya was preferable to a government led by the $\mathrm{MCP}^{82}$.

While without the military component the resettlement policies would have been impossible, they were a key to victory especially in the geographical and social conditions of Malaya, where such a strategy could be followed because it had the support of a vast number of the Malay population and because the government had the resources and willingness to pursue it. It is very hard to think that this is an experience which could be exported in a different setting; while similar efforts - with even greater brutality - were successful in Kenya, in Vietnam they failed spectacularly, with serious effects on the American military effort in the country ${ }^{83}$.

\section{Intelligence}

In insurgencies that do not escalate to the stage of conventional warfare the military superiority of government forces, both numerically and technologically, is nearly always crushing. The guerrillas seldom score more than a few sparse tactical victories, more often than not in carefully prepared ambushes. When confronted with the full force of the regular

\footnotetext{
${ }^{78}$ For instance, Victor Purcell, Malaysia, London: Thames and Hudson, 1965, 112-113.

${ }^{79}$ David French, Army, Empire, and Cold War, 123; Gregory Blaxland, The Regiments Depart, 87 gives 26 dead.

${ }^{80}$ Karl Hack, Defence and Decolonisation in Southeast Asia, 114.

${ }^{81}$ The MCA regulations were discussed before their adoption with the High Commissioner himself, telegram from H. Gurney to Creech Jones CO537/4242 no 1, 19 December 1948 in A.J. Stockwell (ed.), Malaya, Part II, 88 .

${ }^{82}$ Kumar Ramakrishna, Emergency Propaganda. The Winning of Malayan Hearts and Minds, 1948-1958, Richmond: Curzon, 2002, 205.

${ }^{83}$ Ian F.W. Beckett, "Robert Thompson and the British Advisory Mission to South Vietnam, 1961-1965" in Small Wars and Insurgencies, Vol.8, No.3 (1997), 41-63.
} 
military, they need do flee or face defeat and knowing this simple reality is enough to highlight the importance of intelligence for the counterinsurgents. In Malaya much as elsewhere, finding the enemy was akin to winning, as the communists' military could not withstand the full power of the British police, army and special forces. This section will examine the organization of information gathering and intelligence analysis during the Emergency, as well as the methods which proved efficient in dealing with the MCP-led rebellion.

It is interesting to note from the beginning a peculiarity of the organization of intelligence in Malaya, which sets the Emergency firmly inside the British tradition of COIN. While other governments, when confronted with armed rebellions, have decided to entrust the military with the task of defeating the guerrillas and therefore they left military intelligence to play the main part in the conflict, the British in most of their colonial conflicts chose to entrust civilian agencies with this mission. This preference came from the persistent view that counterinsurgency is mostly a matter of restoring law and order, not of military victory, and that civilian agencies are the most legitimate and appropriate organizations for accomplishing this $\operatorname{task}^{84}$. Considering their enemies closer, at least in behaviour, to armed bandits rather than political opponents, the British authorities thought that a police-type information gathering structure is better suited to dealing with them than military intelligence structures, which were designed for conventional warfare. There were, of course, other reasons of a more practical nature, such as the fact that the military intelligence structures of the army units in Malaya were woefully inadequate ${ }^{85}$; in many instances they consisted of just one officer either deemed by his superiors unfit for command or staff roles, or one who had intelligence tasks as additional burdens to a larger administrative role.

The main organizations dealing with civilian intelligence matters before the beginning of the Emergency were the Malayan Security Service and the Criminal Investigations Department of the Police. While the first concerned itself mainly with political intelligence, targeting immediately after the war all groups opposed to the continuation of British rule in Malaya, the second was monitoring all incidents concerning armed violence and had a good documentation and identification filing system which played a vital part in the early stages of the conflict ${ }^{86}$. Accounts of their efficiency differ, but some accomplishments cannot be denied. The MSS, despite being understaffed especially in what regards Chinese affairs ${ }^{87}$, played a very important role in the spring of 1948 and in the early weeks after the declaration of Emergency in June the same year, helping the authorities first to break-up union action and then to arrest many of the known communists activists and sympathizers early on in the conflict. Intelligence agents working with the crack paramilitary unit Ferret Force helped in the discovery and killing on 16 July 1948 of Lau Yew, the leader of the Military Committee

\footnotetext{
${ }^{84}$ Richard Clutterbuck, The Long Long War, 178.

${ }^{85}$ Field intelligence was nearly lacking in 1948, John Coates, Supressing Insurgency. An Analysis of the Malayan Emergency, 1948-1954, Boulder: Westview Press, 1992, 34.

${ }^{86}$ Especially on the Security Service see Leon Comber, "The Malayan Security Service (1945-1948)" in Intelligence and National Security, Vol. 18, No. 3 (2003), 128-153.

${ }^{87}$ David French, Army, Empire, and Cold War, 113.
} 
of the MCP, a serious blow to that organization ${ }^{88}$. The MSS, through preventive work, also prevented generalized riots in the early phase of the conflict ${ }^{89}$.

Internal squabbles and lack of confidence in what the MSS could accomplish, combined with a conviction that the Emergency took the service by surprise ${ }^{90}$ eventually led to its demise through a take-over of its functions by a strengthened Malayan Special Branch (SB), a part - like in the United Kingdom - of the local police. In time, the authorities ensured that the entire intelligence effort in Malaya was run by the SB, hoping that centralization would lead to strategic success ${ }^{91}$. They could reasonably expect the military intelligence structures and regular units to acquiesce this power structure because current army regulations and decades-old traditions concerning imperial policing, based on the works of Callwell and Gwynn, were defining the roles of the armed forces in counterinsurgency as support to the actions of the civilian government.

Many resources were invested in the new organization, especially concerning personnel $^{92}$. Leaders with experience in colonial affairs in India and Palestine were brought in. Also many lower-ranking cadres with service during the Jewish uprising in Palestine, especially police sergeants, where brought by the hundreds to serve in the SB or in the police forces proper. All military units were eventually required to transmit all the information they gathered in the field to local officers of the $\mathrm{SB}^{93}$. Ample debriefings after any mission in the field were compulsory. To insure the smoothness of this apparent civilian intrusion in military affairs the government seconded between two and three dozen army military intelligence officers to the Special Branch ${ }^{94}$. These officers fulfilled two main tasks; the first was the analysis of information for operational purposes and the second, no less important, to serve as a transmission belt between regular military units and the civilian leaders of the $\mathrm{SB}^{95}$. The other main British agencies with intelligence attributions, the MI5 and MI6 concerned themselves with strategic information and did not play a direct role against the communist guerrillas.

In addition to an expansion of personnel by bringing in British specialists, the SB was greatly strengthened over the years by the recruitment of a substantial number of Chinese and Chinese-speaking agents. This was extremely necessary, given the paucity of such workers in the early phases of the conflict. Their role was fundamental in interrogating captured and surrendered enemy personnel, in reading captured documents, in producing fake propaganda

\footnotetext{
${ }^{88}$ Robert Jackson, The Malayan Emergency. The Commonwealth's Wars 1948-1966, London: Routledge, 1991, 28.

${ }^{89}$ Richard Clutterbuck, The Long Long War, 32-33

${ }^{90}$ Geoffrey Fairbarn, Revolutionary Guerrilla Warfare, 138-139.

${ }^{91}$ Georgina Sinclair, “"The Sharp End of the Intelligence Machine': The Rise of the Malayan Police Special Branch 1948-1955" in Intelligence and National Security, Vol. 26, No. 4, (2011), 460-477.

92 The evolution of Special Branch numbers was: in 194812 officers and 44 inspectors, in 1953123 officers and 195 inspectors, Karl Hack, "British Intelligence and Counter-Insurgency in the Era of Decolonization: The Example of Malaya" in Intelligence and National Security, Vol. 14, No. 2 (1999), 128.

${ }_{93}$ Charles Townshend, Britain's Civil Wars, 29.

${ }_{94}^{94}$ For the reorganization, especially under Templer, see Richard J. Aldrich, The Hidden Hand, 506-507.

95 Anthony Short, The Communist Insurrection in Malaya 1948-1960, 363.
} 
and in crafting targeted messages aimed at certain guerrillas and guerrilla groups ${ }^{96}$. Chinese officers in the SB and the police also held in the consolidation of bonds between the elite of their ethnic group and the Malayan and British leaders working towards a controlled transition towards independence.

The methods employed and avenues taken in defeating insurgency in Malaya, were, like in many other COIN campaigns, a mixture of police work, counter-terrorism and military intelligence procedures such as scouting. It would be hard to make judgements as to which particular method was the most successful, as the records are still not completely open, and there is much to learn also from failures and enterprises that only yielded limited success.

Intelligence agencies everywhere would prefer informative penetration, through the placement or recruitment of agents inside the enemy organization, as it can provide with precious information on most aspects of organization, training, tactics, plans and leadership. Great victories could be scored by informative penetration, an assertion amply proven in a COIN fought in the same time as Malaya: a single agent placed inside the headquarters of the Huk communist rebels in the Philippines provided information which led to the arrest of 1175 and the destruction of that organization's logistic network. No such major success was achieved in Malaya during the Emergency, although one could probably argue that before its beginning the handling of Lai Tek provided major benefits in avoiding an immediate postwar insurgency ${ }^{97}$.

Once the MCP and its military wing, first styled Malayan Peoples' Anti-British Army and then renamed the Malayan Races Liberation Army (MRLA) took to the jungle it became extremely difficult to plant agents or moles inside the jungle camps $\operatorname{proper}^{98}$. The few agents that were attracted were hard to contact and debriefing was next to impossible without permanently removing them from the rebel organization". If immediately "turned", the Special Branch could return to the jungle surrendered enemy personnel (SEP) within 24 or 48 hours since they were apprehended. Waiting for longer would jeopardize their successful reinsertion in the communist guerrilla groups, and the counter-intelligence structures of the MRLA were particularly vigilant and ruthless. Throughout the conflict the communists routinely purged their ranks in the hunt for British spies (or "running dogs"), which contributed to the near-impossibility of informative penetration ${ }^{100}$.

Of far greater use was the recruitment of agents inside the support network of the communists or in the "New Villages". The voluntary agents and those willing to cooperate when offered the possibility were offered cash stipends and - at the end of their mission relocation to Hong Kong ${ }^{101}$. The recalcitrant would be coerced through threats of various

\footnotetext{
${ }^{96}$ Leon Comber, Malaya's Secret Police 1945-60. The Role of the Special Branch in the Malayan Emergency, Singapore: ISEAS Publishing, 2008, 133.

97 John S. Pustay, Counterinsurgency Warfare, New York: The Fee Press, 1965, 106-109.

98 Anthony Short, The Communist Insurrection in Malaya 1948-1960, 362.

${ }^{99}$ Leon Comber, Malaya's Secret Police, 81-82.

${ }^{100}$ Karl Hack, "British Intelligence and Counter-Insurgency", 132.

101 Thomas R. Mockaitis, British Counterinsurgency, 1919-1960, 117; Martin Shipway, Decolonization and its Impact, 168. Substantial sums were offered for the heads of the guerrillas, 30000 pounds for Chin Peng, 15000
} 
intensities which could culminate with the placement of communist propaganda materials in their houses ${ }^{102}$. Facing the prospect of imprisonment, many chose to work as informants for the government. The information they provided targeted the Min Yuen communist support organization revealing the names and moves of its members, while also providing insights into the MCP's attempts to directly approach the villagers ${ }^{103}$. Among the most precious agents the SB could have were the couriers who moved information between the jungle guerrillas and the Min Yuen in the villages ${ }^{104}$. These couriers were recruited by the rebels among the rubber tappers, who had valid reasons to be alone for a long time in the jungle without arousing suspicion ${ }^{105}$. When government intelligence managed to turn them into their own agents, the couriers helped in tracking enemy movements and camps and in many occasions provided the necessary information for organizing ambushes, which throughout the conflict were the most efficient tactic for killing and capturing the largest number of insurgents ${ }^{106}$.

Handling the informers without revealing their identities, particularly in the tightlyknit Chinese rural communities was a difficult task, requiring time and subtlety. SB officers and other intelligence agencies working for the SB would conduct large-scale searches and interrogations of whole villages as a cover for the debriefing of their agents. For instance, the Chinese Affairs Department (supposedly an aid agency) was mounting Operation Letter Box, involving visits at dawn in Chinese villages by teams of intelligence officers who administered questionnaires in Chinese and assured the locals that the answers would be anonymous ${ }^{107}$. Interviews were conducted in private on a one to one basis ${ }^{108}$. It was more of a psychological warfare operation than intelligence gathering, for it served mostly to make insurgents nervous and keep them on guard.

The other main sources of human intelligence were, of course, SEPs and captured enemy personnel. Though usually apprehended by army units, special forces teams or jungle police companies, their main interrogation was undergone in safe locations by SB officers ${ }^{109}$. Information concerning immediate enemy moves was fast relayed as tactical intelligence to the units on the ground, with the hope that it would lead to the discovery of other insurgent groups or camps ${ }^{110}$. But the interrogators were also trying to extract information about enemy organization, morale, identity, leadership, weapons and patterns of operation. Larger, analytical documents based on these interrogations formed the strategic intelligence read by the military and civilian decision makers. It is interesting to note that the British pioneered

for Yeung Kwo, the military chief and 15000 for Lau Lee, the propaganda leader or chief, see Julian Paget, Counter-Insurgency Campaigning, 50 fn. 2.

${ }^{102}$ Richard J. Aldrich, The Hidden Hand, 508.

${ }^{103}$ Karl Hack, Defence and Decolonisation in Southeast Asia, 125-126.

${ }^{104}$ Brian Stewart, "Winning in Malaya: An Intelligence Success Story" in Intelligence and National Security, Vol. 14, No. 4, (1999), 279.

105 John Coates, Supressing Insurgency, 157-158.

${ }^{106}$ Director of Operations, Malaya, The Conduct of Anti-Terrorist Operations in Malaya, $3^{\text {rd }}$ edition, 1958, XI.

${ }^{107}$ Brian Stewart, "Winning in Malaya", 276.

${ }^{108}$ On the procedures for interrogation, both for civilians and troops see ibid., XIV.

${ }^{109}$ While allegations of torture during interrogations were made, few proof substantiates them so far, see Leon Comber, Malaya's Secret Police, 83.

${ }^{110}$ Anthony Short, The Communist Insurrection in Malaya 1948-1960, 364. 
the use of sociologists and their methods in the formulation of profiles of the rebels through interrogations based on scientific research methods ${ }^{111}$.

Other elements were of major use in the acquiring of information. In the early stages of the Emergency, before a concerted effort to acquire and make good use of human intelligence was on its way, the study of captured documents was a main source of information $^{112}$. It helped establish the moves, identities and the general organizational structure of the insurgent regiments ${ }^{113}$. The documents were generally obsolete by the time of their deciphering (a process slowed by the initial lack of Chinese-speaking officers) and unusable as tactical and operational intelligence. However, they could provide a good strategic picture of the insurgency, especially when documents of the Central Committe of the MCP outlining a Maoist-inspired campaign or revealing a drop in morale were eventually captured.

In a more gruesome manner, the bodies of dead insurgents - killed in fire fights or discovered in the jungle were used as sources ${ }^{114}$. Regulations asked for troops in the field to remove the killed guerrillas and to transport them to safe bases for identification, either by carrying them or by calling, when possible, for helicopter evacuation. In the early stages, when evacuation was impossible, some troops would chop up the head and hands of the guerrillas and leave the rest of their bodies where they fell ${ }^{115}$. This became a court martial offence eventually and it was replaced by taking at least two photos of each cadaver if evacuation was impossible. This method allowed for keeping good track of progress and carefully identifying the guerrillas, with the aim of extracting further information from their known relatives and friends ${ }^{116}$.

As the MRLA was quite unsophisticated from a technological perspective and made virtually no use of electronic communication systems ${ }^{117}$, signals intelligence was of no major importance in collecting information of the guerrillas. The SB attempted though to put communication technology in the service of the COIN campaign through the use of specially modified radios which were placed on the market with the hope that they would fall in the hands of the communists. Incorporating a homing device, it was hoped that the interception of the use of these radios would lead to the location of a rebel headquarters. Apparently, success was limited ${ }^{118}$.

While the Special Branch intelligence effort focused on informative penetration, the recruitment and running of agents, identification of dead enemy personnel, the deciphering of

\footnotetext{
${ }^{111}$ Lucian W. Pye, Guerrilla Communism in Malaya. Its Social and Political Meaning, Princeton: Princeton University Press, 1956.

112 Peter Dennis, Jeffrey Grey, Emergency and Confrontation. Australian Military Operations in Malaya and Borneo 1950-1966, Sydney: Allen\&Unwin, 1996, 97.

${ }^{113}$ Richard J. Aldrich, The Hidden Hand, 500.

${ }^{114}$ Malaya memorandum by O. Lyttelton, CAB 129/48, C(51)59, 21 December 1951 in A.J. Stockwell (ed.), Malaya, Part II, 344.

115 Brian Stewart, Smashing Terrorism in the Malayan Emergency. The Vital Contribution of the Police, Selangor: Pelanduk Publications, 2004, 24.

${ }_{116}$ Director of Operations, Malaya, The Conduct of Anti-Terrorist Operations in Malaya, $3^{\text {rd }}$ edition, 1958, XIV.

${ }^{117}$ Anthony Short, "The Malayan Emergency", 66.

${ }^{118}$ Richard J. Aldrich, The Hidden Hand, 504.
} 
captured documents and a limited signals intelligence program, the British Army units focused on gathering intelligence through the traditional approach of scouting ${ }^{119}$. While local Malay troops and policemen were of good use, most accounts of the Emergency place a great emphasis of the recruitment of Iban trackers from Borneo ${ }^{120}$. Living their whole lives in very similar conditions as the communists were attempting to do in Malaya, their experience in finding the enemies through treacherous jungle was great; the fact that some of them had been practising head-hunters undoubtedly helped. The Iban initially came in limited numbers of a few dozens, were attached to army units as their scouting element and also passed their expertise to regular soldiers, of whom especially the Gurkhas proved very good students ${ }^{121}$. In time their numbers grew enough that they were able to form an entire battalion, the Sarawak Rangers. Scouting was recognized as an extremely important information-gathering source by the Army leadership, which included a special course on tracking in the curriculum of its Training Centre of the Far East Land Forces ${ }^{122}$.

\section{Military operations and the elimination of rebel groups}

The present section will examine military operations during the Malayan emergency, with special attention paid to force structure and numbers, operational options such as sweeps, cordoning, search and destroy missions, ambushes, deep strikes and air operations. The connection between intelligence and operations will also be examined, especially in the context of the elimination of armed groups of the MCP.

A significant number of academics, writing years and decades after the events, have judged the initial reaction of the British military commanders as inadequate and ineffectual and argued that it took years, as many as four, until coherent and efficient operations were finally undertaken. At the face of things and if we only assess military efficiency and success by the number of enemies killed or captured and by a standard of total victory, these opinions might stand true. But they do little justice from a historical perspective and, arguably, even from a strategic one.

When the Emergency was declared in the second half of June 1948 guerrilla attacks had already killed dozens of people in the preceding weeks. The British military command, devoid of intelligence coming from the inner structures of the MCP, had little insight in the intentions and military dispositions of the enemy. While it was generally known that the guerrillas of the MRLA numbered around 8000 fighters divided in twelve regiments and the type and quantity of weapons of their disposal was more or less easy to estimate, hardly anything was known about the strategy the rebels intended to pursue. Only much later in 1949 were captured documents of the Communist leadership that gave inkling into overall

\footnotetext{
${ }^{119}$ David H. Ucko, "The Malayan Emergency", 23.

${ }^{120}$ Gregory Blaxland, The Regiments Depart, 81.

${ }^{121}$ Robert Jackson, The Malayan Emergency, 38.

122 John Coates, Supressing Insurgency, 167.
} 
enemy perceptions and strategy. Not knowing whether the rebels intend to pursue a terrorist campaign, a skirmishes strategy or an all-out attempt to establish safe bases inside the country from which to launch conventional attacks, the government's commanders also had to take into account the feeble state of the forces at their disposal ${ }^{123}$. Although on paper the number of available battalions in June 1948 looked sufficient, most of them were under strength, especially the Gurkhas who took over a year and a half to reach full complement ${ }^{124}$. Reinforcements could be brought in and indeed they came, from the United Kingdom and from Hong Kong, but it would take weeks and months before they could be put to good effect in the field ${ }^{125}$. The police was in no state, either numerically or through its training, to be of help against the guerrillas.

It is in this context that one should try to understand the initial military moves of the government commanders. One of the first actions was to create two paramilitary units, Shawforce and Ferret Force, who would make great use of available human resources specialized in jungle warfare and take the fight to the enemy's ground. The Ferret Force would become the best known of the two. The unit was composed of former officers of the Force 136 (the British commando group and liaison with the communist rebels during the Japanese occupation), Malayan policemen and local British planters and overseers of the tin mines ${ }^{126}$. The Ferret Force was structured in six teams of 15 men and operated mostly independently in a strike role, sometimes achieving significant success. As a small force, though, it was only as much as it could do. To add to that, its maverick status inside the British government forces made it hard to accept by both political officials and Army generals and eventually it was disbanded at the end of 1948. Its expertise was solid enough though and many of its members became trainers for other, regular military units and its experienced commanders led the jungle warfare school established to teach incoming officers and NCO's ${ }^{127}$.

But the commando forces were just a small element of the initial military reaction of the British generals. Using the forces they had at their disposal and - in the months that followed - the reinforcement brigades, conventional military operations were launched against the communist insurgents. These operations took the form of sweeps though the rural areas experiencing attacks and soon moved into the jungle fringes. Whole battalions would move in specific areas in full strength, combing at best they could the villages, roads and much more difficult - the jungle ${ }^{128}$. The sweeps were from early on combined arms operations, with artillery pounding the target areas before infantry moved in and Spitfire fighter planes machine-gunning suspected enemy positions. In nearly all of the cases but especially in the early phases of the conflict the sweeps were "blind" operations, with little or

\footnotetext{
${ }^{123}$ Richard Clutterbuck, The Long Long War, 42.

${ }_{124}$ Anthony Short, The Communist Insurrection in Malaya 1948-1960, 114.

125 Gregory Blaxland, The Regiments Depart, 81.

126 Julian Paget, Counter-Insurgency Campaigning, 52.

${ }^{127}$ Daniel Marston, "Lost and Found in the Jungle", 98.

${ }^{128}$ An early example is the September 1948 big offensive mounted in Johore led by the Ferret Force and three battalions of infantry. Twelve camps were destroyed; vast caches of ammunition were discovered as well as propaganda books. 27 insurgents were killed in the operation, Gregory Blaxland, The Regiments Depart, 82-83.
} 
no tactical intelligence available ${ }^{129}$. In terms of killed and captured enemies, the large sweeps produced very little for the amount of effort involved. But one could argue that the swift, massive, violent reaction of the government forces prevented the communist guerrillas from ever being able to grow from a small, unconventional force into a serious military threat. Complementing the sweeps, the decision of positioning company-strength forces in strategic positions between villages and between villages and rubber plantations and tin mines vastly disrupted enemy action. These quick reaction groups could reach a position in a few minutes after being attacked and deliver massive support for the defenders ${ }^{130}$. The sweeps and the strategic-placed companies effectively forced the MRLA to stop operating in battalion and company strength, vastly decreasing its firepower during attacks and therefore its prospect for anything else than minimal success.

It is harder to justify the option for continuing the sweeps involving large forces for many years after the initial operational objective had been achieved. Indeed, despite the operational focus shifting to other options from 1949 on, the sweeps remained a feature of military action in Malaya basically until the end of massive British involvement ${ }^{131}$. Until the mid - 1950s and even later (so years after the departure of General Sir Gerald Templer, who according to many completely changed British approach in Malaya), the armed forces would sweep the jungle in vast numbers with massive air and artillery support, after previously dividing it in squares according to maps obtained through careful air photographing of the target $\operatorname{areas}^{132}$. Despite mediocre success at best, the operations were continued, apparently being considered appropriate by each wave of British officers and generals sent from commands in Germany to serve for a time in Malaya. Commonwealth forces were also trained for these specific operations rather than any different options; the Australian battalions for instance were taught to place an emphasis on conventional tactics at their training base at Canungra and they were indeed called to operate in such fashion when they were eventually deployed ${ }^{133}$. One could wonder whether the British Army did indeed become by the middle of the conflict the efficient "learning institution" that experts such as John Nagl claimed it was ${ }^{134}$.

Large scale sweeps were used in conjunction with a set of other military operations right from the start of the Emergency. Cordoning and searches stood prominently among these and were features of military action in Malaya throughout the conflict. While the purpose of the sweeps had been to dislodge the enemy from areas supposedly under its control or its threat and in this regard were more clearly in the framework of conventional military approaches, cordoning and searches were mostly pursued in the areas already under

\footnotetext{
${ }^{129}$ Comprehensive descriptions of sweeps can be found in John Coates, Supressing Insurgency and Sam C. Sarkesian, Unconventional Conflicts in a New Security Era.

${ }^{130}$ Julian Paget, Counter-Insurgency Campaigning, 53.

${ }^{131}$ Richard Clutterbuck, The Long Long War, 52.

132 In Operation Nawab (in early 1949) two reinforced battalions combed an area while also setting up ambushes. For all their efforts they reported one kill and 59 arrests. In October 1949 in Operation Leo 24 platoons patrolled an area of Johore for ten days, with artillery and bombers pounding the area in advance. They accomplished nothing, John Coates, Supressing Insurgency, 150.

${ }_{133}$ Peter Dennis, Jeffrey Grey, Emergency and Confrontation, 90-91, 93-95.

${ }^{134}$ In his widely read Counterinsurgency Lessons from Malaya and Vietnam, Learning to Eat Soup with a Knife, Westport: Praeger, 2002.
} 
some measure of government control. Their outlook owed more to policing actions than military operations per se, being conceived as criminal-apprehending tactics - which suited the description of guerrillas as "bandits", prominent until General Gerald Templer had it changed to "communist terrorists" 135 . In the regular cordoning and search operations a force usually of company or platoon strength would surround a village, block the roads leading to and from it and would conduct, together with intelligence officers of the SB a thorough search of the houses and a screening and interrogation of the inhabitants. After the identification cards with photograph and fingerprints had been issued, the cordoning and search operations were an efficient method for reinforcing population control. While this operational option sometimes produced good intelligence and even led to the capture of insurgents and their sympathizers, it was helpful, but not in any way decisive for military victory $^{136}$.

Both large-scale sweeps and cordoning and search operations failed to deliver victory by themselves for a multiplicity of reasons, dealing not only with the initial scarcity of troops, preparation and intelligence, but also with the MCP's tactical adaptation to it. Being frustrated in their attempts to establish safe bases in the northern regions of Malaya ${ }^{137}$, the communist insurgents moved to an outright Maoist strategy after December $1948^{138}$. The MRLA established camps deep in the jungle and consolidated its logistical support and network intelligence among the Chinese community and the Aborigines. Instead of large scale attacks, made impossible by vigorous government action, the classic guerrilla tactics of hit and run and ambushes became the staple of insurgent action in the country ${ }^{139}$.

These attacks became more and more furious as the resettlement program removed the Chinese squatters from easy to reach positions and put them under strong governmental control. Indeed, the height of Communist strikes in Malaya was reached simultaneously with the peak of the internal deportation program ${ }^{140}$. Until the new villages were consolidated and enough security was provided, the insurgents' attacks could be devastating and a significant number of ethnic Malay policemen made deals for their lives with the insurgents, allowing them to penetrate the villages. Some lucky strikes and ambushes could score significant morale and propaganda victories, such as the killing of 18 policemen on 23 March $1950^{141}$. Famously, a guerrilla group ambushed on 7 October 1951 the car of the British High Commissioner Sir Henry Gurney, killing him.

\footnotetext{
135 Gregory Blaxland, The Regiments Depart, 105.

136 In Operation Cascara, mounted in September 1949 by the $2^{\text {nd }}$ Coldstream Guards, 1400 people were screened, one insurgent was killed and 33 guerrillas were apprehended, David French, Army, Empire, and Cold War, 114.

${ }^{137}$ Gregory Blaxland, The Regiments Depart, 81.

${ }^{138}$ Khong Kim Hoong, Merdeka!, 138.

${ }^{139}$ On 24 December an ambush against Gurkhas in Kelantan resulted in four troops killed and 13 wounded. On 31 December 1948 the $4^{\text {th }}$ Hussars lost in an ambush in Kelantan the commander of the patrol and six officers killed. The guerrilla ambushes continued in January 1949 in Kedah with Gurkhas losing eigth dead, ${ }^{139}$ Gregory Blaxland, The Regiments Depart, 87.

${ }^{140}$ Gregory Blaxland, The Regiments Depart, 97.

${ }^{141}$ The guerrillas lost 29 dead to achieve this victory, Robert Jackson, The Malayan Emergency, 33-34.
} 
However, once the resettlement was completed and the Malay police guarding it was replaced by a strong and armed Chinese Home Guard, once massive reinforcements led to the number of available troops increasing to 4000 and the number of policemen to 67000 and once jungle warfare was taught to arriving officers, NCO's, soldiers and policemen, the British were in a position to launch more flexible operations against the insurgents ${ }^{142}$.

The first important operational change was to switch from battalion and companystrength missions to a vastly higher number of platoon and squad-strength operations ${ }^{143}$. This was permitted by the initial large scale operations which made it impossible for the MRLA to attempt large-scale moves. The change allowed for a vast increase in the number of patrols in the jungle, which obviously meant stronger and constant pressure on the insurgents ${ }^{144}$. Regular patrols lasted around five days, being limited by the quantity of food the troops could carry and covered a variable area depending on the terrain, roughly of a radius between 5 and 20 miles $^{145}$. The difficulty of patrolling in the jungle cannot be overemphasised. In addition to the humid climate, low light which predisposed many to melancholia, difficult terrain and slow marches one needs to add the recurring dangers of falling trees, lice, leeches, snakes and even tigers. The thick bush made it very difficult to spot enemy moves and camps, rendered offensive action difficult and escapes easy ${ }^{146}$. All of this combined to make patrolling an extremely strenuous and frustrating enterprise, especially when combined with its low efficiency in terms of kills. It is estimated that it took 6500 hours of patrolling to spot an insurgent and longer to kill one ${ }^{147}$.

Patrolling by itself would have never led to notable success except for putting constant pressure on the insurgents, but combined with changes in the force structure and composition and other operations it did contribute to victory. The force changes had much to do with eventual adaptation to the conditions of asymmetric warfare in the jungle ${ }^{148}$. The impact of the trackers from Borneo has already been mentioned. Far better training was offered by the Far East Land Forces command to incoming officers and troops, with special counterinsurgency courses ${ }^{149}$. Operational regulations were summed up by Lt. Col. William Walker in a textbook, The Conduct of Anti-Terrorist Operations in Malaya, which became a Bible for the British units fighting in the Emergency.

Special Forces were raised, such as the Malayan Scouts, who inherited the tradition of the Ferret Force and became one of the numbered commandos of the Special Air Service ${ }^{150}$.

\footnotetext{
${ }^{142}$ Karl Hack, "The Malayan Emergency as Counter-Insurgency Paradigm".

143 David H. Ucko, "The Malayan Emergency", 22; David Ucko, "Countering Insurgents through Distributed Operations: Insights from Malaya 1948-1960” in The Journal of Strategic Studies 30: 1 (2007), 47 - 72.

${ }^{144}$ Richard Clutterbuck, The Long Long War, 53; Daniel Marston, "Lost and Found in the Jungle", 101.

145 Special Forces, especially the SAS, could survive for much longer in the jungle, Robert Jackson, The Malayan Emergency, 37.

${ }_{146}$ Brian Stewart, Smashing Terrorism in the Malayan Emergency.

147 John S. Pustay, Counterinsurgency Warfare, 87.

${ }^{148}$ And their vast increase in numbers. Already when General Briggs took command in April 1952 he had at his disposal 40000 troops and 80000 auxiliaries, Martin Thomas et. al., Crises of Empire, 62.

${ }^{149}$ Daniel Marston, "Lost and Found in the Jungle", 98.

${ }^{150}$ Stephen Twigge, Edwards Hampshire, Graham Macklin, British Intelligence. Secrets, Spies and Sources, Kew: The National Archives, 2008, 104.
} 
Outside the military per se, Police Jungle Companies made of Malay troops, Borneo trackers and officered by British personnel emerged as specialised units. Also notably was the switch from a military effort conducted by forces from the United Kingdom to one in which units from the rest of the empire shared the burden ${ }^{151}$. As early as March 1951 the Chief of the Imperial General Staff suggested using colonial troops as best suited to fight colonial insurgencies $^{152}$. In the course of the conflict a serious contribution was brought by the battalions of the King's African Rifles, the Gurkhas and the Fijian Regiment, who achieved systematically higher kill ratios than the European battalions ${ }^{153}$.

Better force structures and improved intelligence led to more successful search and destroy deep-strike missions in the jungle ${ }^{154}$. With scouting, fighting and support platoons operating in conjunction, British forces struck at suspected communist camps. In the rare cases when - mostly through excellent intelligence or more often through enemy negligence - the guerrillas were surprised, the outcome of the strike was the destruction of the insurgent groups. In most cases though, government forces found empty camps ${ }^{155}$; after a search for any possible intelligence materiel, resulting sometimes in the discovery of important documents, the troops would torch the huts. More importantly, they were instructed to systematically destroy any food or any cultivated fields, insuring that returning insurgents would starve. It is important here to mention that military units were systematically destroying across Malaya all cultivate fields that were not under government control and were suspected of being used by the $\mathrm{MCP}^{156}$.

Deep strikes became particularly efficient, at least in the assessment of governmental authorities, after Police Jungle Companies established permanent forts inside the jungles, allowing them to operate in the middle and in the back of the MRLA ${ }^{157}$. To this was added the alliance struck with the Aborigines, who were offered by the government food and medical supplies and assistance in return for their cooperation ${ }^{158}$. In due course, special Aborigines units were raised and added to the British forces. Operating in their own environment, they proved to be among the most efficient forces in terms of the kill ratio achieved $^{159}$.

There seems to be a general agreement that the most successful operations against the MRLA were intelligence-conducted ambushes. With information coming from captured documents, interrogations in the New Villages, the debriefing of SB agents among the Min

\footnotetext{
${ }^{151}$ In 1952 the forces in Malaya were 10 British battalions, 8 Gurkha, 5 Malay, 2 African and one from Fiji, Gregory Blaxland, The Regiments Depart, 102.

${ }_{152}$ Cabinet Meeting assessing the progress of the Briggs plan PREM 8/1406/2 GEN 345/8, 13 March 1951 in A.J. Stockwell (ed.), Malaya, Part II, 285.

${ }^{153}$ John Coates, Supressing Insurgency, 166-167.

${ }^{154}$ Ian F. W. Beckett, Modern Insurgencies and Counter-insurgencies, 103.

155 And thus the missions had their opponents, see Robert Thompson, Defeating Communist Insurgency, 35.

156 There was also an attempt to use air power in the destruction of the crops, without success, E.D. Smith, Counter-insurgency Operations: Malaya and Borneo, 28.

${ }^{157}$ On their organization as well as those of other bases established by Special Forces see The Conduct of AntiTerrorist Operations in Malaya, VI.1.

${ }_{158}^{15 u}$ Julian Paget, Counter-Insurgency Campaigning, 72.

159 John Coates, Supressing Insurgency, 159.
} 
Yuen couriers but most importantly from captured or surrendered enemy personnel, British units surrounded and blocked roads and points believed to be travelled at certain times by insurgents. When successful, entire enemy groups could be destroyed ${ }^{160}$. However, the ambushes depended for their success not only on good, reliable and fast transmitted information, but also on good organizational skills of the officers commanding the involved units. The relatively high rate of failure was often blamed on this last aspect ${ }^{161}$. In the latter stages of the conflict, especially after 1955, the efficiency of the ambushes was increased by the employment of counter-gangs, the so-called Q squads ${ }^{162}$. Formed by turncoats (gathered from an organizational perspective in the Special Operational Volunteer Force) and SB officers, these units operated in the jungle in the pretence of being guerrillas. At certain times they would turn against their comrades, killing or capturing them ${ }^{163}$.

The military effort in Malaya was vastly aided by the air operations conducted in support of land forces. Throughout the conflict bombers and fighters of the Royal Air Force conducted strikes at suspected enemy areas, camps and concentrations ${ }^{164}$. From an outright quantitative perspective, although the ordnance dropped came in large quantities, very few guerrillas were killed. However, the psychological effect was deep and led some of the insurgents to surrender ${ }^{165}$. Transport aircraft were instrumental in delivering supplies for forces operating deep in the jungle. Without precise timing and the systematic and prompt delivery of food, ammunition and medical supplies at pre-established drop points the patrols and deep-jungle operations would have been by necessity much shorter. Jungle forts would have been impossible to maintain in the absence of air resupply ${ }^{166}$. Starting in 1952 helicopters made their presence felt in Malaya to a very important degree. Their main contribution to offensive actions was transporting troops for deep-strike operations. Though initially limited because of the small size of the helicopters, this improved in time. They were also important for transporting wounded troops and the dead enemy personnel for identification by intelligence officers in the rear areas ${ }^{167}$. Overall, the helicopters transported 5000 casualties, 19000 passengers, 110000 troops and carried 2.5 million pounds of supplies and ammo ${ }^{168}$.

A portrait of military operations against communist insurgents in Malaya would be incomplete without a mentioning of the psychological warfare efforts, of the propaganda

\footnotetext{
${ }^{160}$ Roy Follows with Hugh Popham, The Jungle Beat. Fighting Terrorists in Malaya 1952-1961, London: Cassell, 1990.

${ }^{161}$ The Conduct of Anti-Terrorist Operations in Malaya, XI mentions that in 1956 out of 50 ambushes 34 were unsuccessful and of those 28 were due to the inadequacy of the troops and their commanders.

${ }^{162}$ Brian Stewart, Smashing Terrorism in the Malayan Emergency, 287.

${ }^{163}$ Stephen Twigge et. al., British Intelligence, 105; Leon Comber, Malaya's Secret Police 1945-60, 165, 285.

${ }^{164}$ Malcolm Postgate, Operation Firedog. Air Support in the Malayan Emergency 1948-1960, London: HMSO, $1992,149$.

${ }^{165}$ The military situation in Malaya, memorandum by Mr. Stratchey CAB 21/1681, MAL C(50)21, 17 June 1950 in A.J. Stockwell (ed.), Malaya, Part II, 235.

${ }^{166}$ Malcolm Postgate, Operation Firedog, 150-152.

167 David Jordan, "Countering Insurgency from the Air: The Postwar Lessons" in Contemporary Security Policy, Vol.28, No.1 (April 2007), 99.

${ }^{168}$ Ian F. W. Beckett, Modern Insurgencies and Counter-insurgencies, 103.
} 
actions targeted at guerrillas ${ }^{169}$. Mostly run (from a content perspective) by a civilian body, the Office of Information in Malaya, psychological warfare comprised a number of important actions. One was the black propaganda section which ran a fake communist journal aimed at confusing guerrillas ${ }^{170}$. Another was the employment of former guerrillas, captured and surrendered enemy personnel in publishing tracts aimed at their former comrades and urging them to quit the struggle.

But the most prominent programs were the distribution of propaganda leaflets and the use of voice aircraft ${ }^{171}$. Over the course of the Emergency the number of leaflets dropped by aircraft in the jungle, describing the government's offers of amnesty increased to tens of millions ${ }^{172}$ and in due turn were published on impermeable paper, insuring their survival in the humid conditions in the jungle. Dakota aircraft took turns flying slowly over certain preselected areas, broadcasting through large loudspeakers 27 -second long messages, repeating after 3 seconds $^{173}$. Sometimes making use of intelligence from captured or surrendered enemies, these messages could mention by name the guerrillas suspected to be in a certain area, urging them to surrender. It is estimated that as the guerrillas were worn out by living in the jungle, were starved and continuously hunted down by mobile operations of the British Army, by 1953 the propaganda efforts paid dividends in increasing the number of surrendered enemy personnel ${ }^{174}$.

The final segment of this paper will deal with relevant military incidents which illuminate how intelligence and tactics fare in the field, in the long years of struggles against the communist guerrillas. The following table presents data concerning the evolution of violence during the most intense years of the Emergency and the numbers of military casualties on both sides, with the mention that, in the parlance of the times, incidents denote encounters when the communists opened fire, contacts incidents in which security forces opened fire $^{175}$ :

\begin{tabular}{|l|l|l|l|l|l|}
\hline Year & 1950 & 1951 & 1952 & 1953 & 1954 \\
\hline Total incidents & 4739 & 6082 & 3727 & 1170 & 1077 \\
\hline Total contacts & 983 & 1911 & 1868 & 1407 & 993 \\
\hline Security forces casualties & 889 & 1195 & 664 & 209 & 241 \\
\hline Insurgent casualties & 942 & 2050 & 2131 & 1695 & 1197 \\
\hline
\end{tabular}

169 The most comprehensive work on the topic is Kumar Ramakrishna, Emergency Propaganda; for this the following fragment see especially 209-210, 215.

${ }^{170}$ Malaya memorandum by O. Lyttelton, CAB 129/48, C(51)59, 21 December 1951 in A.J. Stockwell (ed.), Malaya, Part II, 346-347.

${ }^{171}$ Julian Paget, Counter-Insurgency Campaigning, 69.

172 The number of leaflets distributed jumped from 30 million in1948 to 53 million in 1950, 77 million in 1953 and over 100 million in any year from 1954 to 1957. Twelve mobile cinemas were also in action in 1948, increasing to 91 units in 1953, able to bring their messages to a million people monthly, see Robert Jackson, The Malayan Emergency, 110.

173 Ibid., 113.

174350 guerrillas surrendered because of targeted propaganda that year, James E. Dougherty, "The Guerrilla War in Malaya", 306. Also see Geoffrey Fairbarn, Revolutionary Guerrilla Warfare, 141.

${ }^{175}$ Sam C. Sarkesian, Unconventional Conflicts in a New Security Era, 72. 
The biggest encounters in Malaya, as could be expected in an asymmetric conflict, resulted from tactical mistakes, either of the communists or the security forces. On 22 January 1950 an insurgent group remained in its camp although its position had been spotted, losing in the ensuing fight 22 of its men. In March 1950 a Malay Regiment platoon returned to its base in Kelantan on the same route it left and in the ambush that followed 17 troops were killed and 6 wounded $^{176}$. On 22 December 1950, after an incident with Gurkhas the previous day, an insurgent group was luckily intercepted by another Gurkha company on a rubber plantation. In the greatest field victory of the Emergency the insurgents lost 35 dead for one Gurkha killed ${ }^{177}$.

Sometimes quick reaction could yield victories for the security forces: the pursuit of the thirty guerrillas which killed Henry Gurney on 7 October 1951 resulted in the capture of five of them and the discovery that they had received support in a village close by, Tras. The local population was detained and the village burned as reprisals ${ }^{178}$.

Intelligence operations and the more or less enforced cooperation of the inhabitants of the "New Villages" with the police started to pay off in May 1950. For instance, a woman informer from Kajang provided intelligence which led to an ambush by security forces in which four rebels were killed and three taken prisoner ${ }^{179}$. More importantly, in July 1952 the Special Branch received information concerning the location of guerrilla leader Liew Kon Kim from one of his former lovers. Hunted down in some swamps for six days by two companies of the Royal West Kent Regiment, he was killed when running away ${ }^{180}$.

It took until 1952 for the Special Branch to map the location and area of responsibility of the insurgent formations. Operation Hive (started on 25 August 1952) in Seremban (the state of Negri Sembilan) covered 25 square miles and was based on the Special Branch's penetration of the communist intelligence system in Seremban. This was accomplished through "turning" guerrillas, a procedure discovered as more efficient than informative penetration. As mentioned in the section concerning intelligence, many of the agents working for the SB were suppliers of the MCP. Some of them were arrested successively in order not to blow up their cover. In the nine weeks of the operation, which involved one Gurkha battalion and 2 SAS squadrons a total of 29 insurgents were eliminated. Among those captured early on was a courier with precious documents which aided in the operation ${ }^{181}$.

A typical deep-jungle operation of the late period of the conflict, "Termite" (JulyNovember 1954) saw an air attack and an air drop of 3 squadrons of the 22 SAS in an area where the rebels lived together with the aborigines. They were followed on the ground by five infantry battalions supported by police, the turncoats of the Special Operations Volunteer

\footnotetext{
${ }^{176}$ John Coates, Supressing Insurgency, 143.

${ }^{177}$ Gregory Blaxland, The Regiments Depart, 90.

${ }^{178}$ Richard J. Aldrich, The Hidden Hand, 503.

${ }^{179}$ Gregory Blaxland, The Regiments Depart, 92.

${ }^{180}$ Ibid., 108.

${ }^{181}$ John Coates, Supressing Insurgency, 152.
} 
Force and allied aborigines. Together they eliminated 15 rebels. The operation continued in 1955 with the establishment of a jungle fort manned by the Police Field Force ${ }^{182}$.

In the later stages of the Emergency desperate guerrillas, hungry, demoralized and influence by government propaganda turned on their leaders. On 6 March 1959 Siu Mah, party secretary for Perak and the commander of the group that ambushed and killed Henry Gurney was killed by his own bodyguard while his two other remaining men had just betrayed him to a Special Branch officer ${ }^{183}$.

The present paper discussed the Malayan Emergency thematically, from the perspectives of population control, intelligence and military operations. In varying degree, they all played their part in ensuring that the British civilian and military authorities won their conflict with the communist insurgents, allowing them to leave an independent Malaya in the hands of a hand-picked elite, the expression of a consensus between Malay, Chinese and local European commercial, financial and industrial interests.

${ }^{182}$ Ibid., $157-158$.

${ }^{183}$ Leon Comber, Malaya's Secret Police 1945-60, 280-281. 